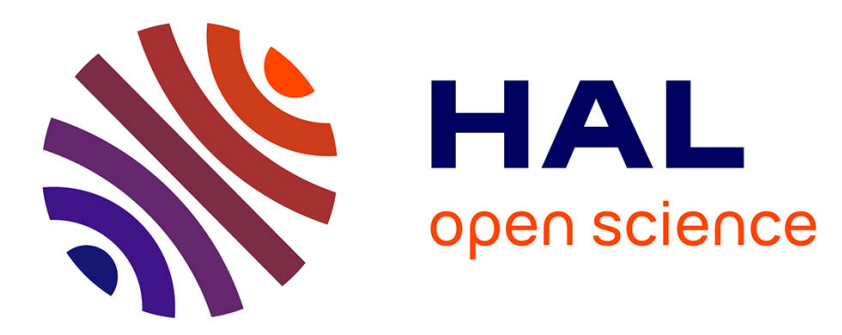

\title{
Distribution patterns of bacterial communities and their potential link to variable viral lysis in temperate freshwater reservoirs
}

Angia Sriram Pradeep Ram, Jitendra Keshri, Télesphore Sime-Ngando

\section{To cite this version:}

Angia Sriram Pradeep Ram, Jitendra Keshri, Télesphore Sime-Ngando. Distribution patterns of bacterial communities and their potential link to variable viral lysis in temperate freshwater reservoirs. Aquatic Sciences - Research Across Boundaries, 2019, 81 (4), 10.1007/s00027-019-0669-5 . hal-03045527

\section{HAL Id: hal-03045527 \\ https://hal.science/hal-03045527}

Submitted on 8 Dec 2020

HAL is a multi-disciplinary open access archive for the deposit and dissemination of scientific research documents, whether they are published or not. The documents may come from teaching and research institutions in France or abroad, or from public or private research centers.
L'archive ouverte pluridisciplinaire HAL, est destinée au dépôt et à la diffusion de documents scientifiques de niveau recherche, publiés ou non, émanant des établissements d'enseignement et de recherche français ou étrangers, des laboratoires publics ou privés. 
1 Distribution patterns of bacterial communities and their potential link to

5

6

7

8 (8) . variable viral lysis in temperate freshwater reservoirs

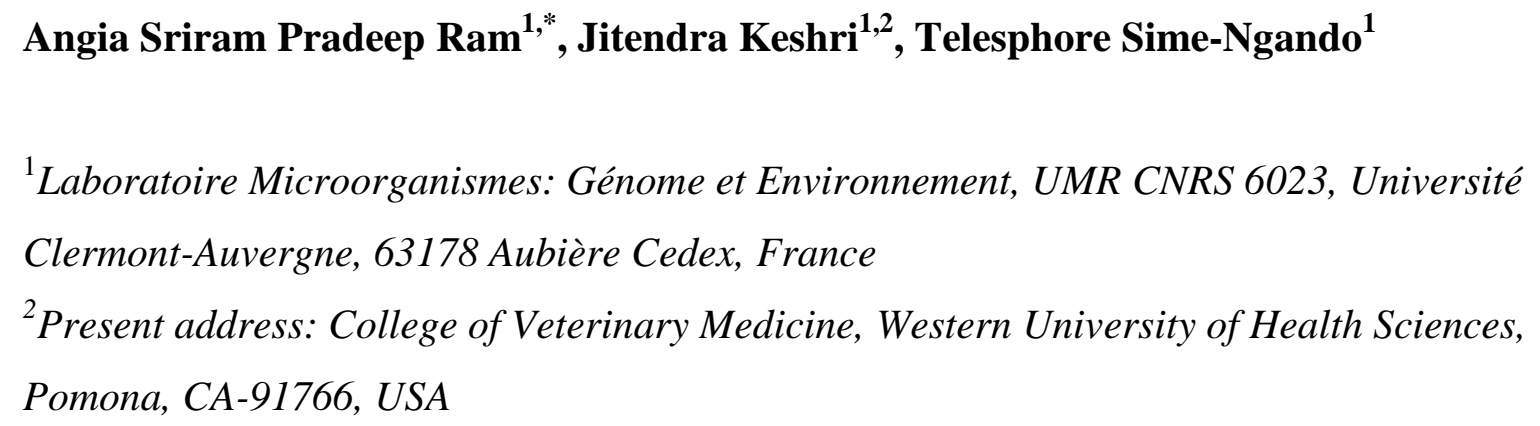

Running title: Viral lysis impacts freshwater bacterial community

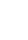
1

\section{*Correspondence: A.S. Pradeep Ram,}

Laboratoire Microorganismes : Génome et Environnement, UMR CNRS 6023, Université Clermont-Auvergne, 1 Impasse Amélie Murat, 63178 Aubière Cedex, FRANCE

E-mail : pradeep_ram.angia_sriram@uca.fr Phone : +33473407463 Fax : +33473407670 


\section{Abstract}

Man-made reservoirs which receive substantial inputs of terrestrial organic matter are characterized by physiologically diverse and distinct bacterial communities. Here we examined bacterial community structure using Illumina MiSeq sequencing of 16S rRNA genes and evaluated the potential role of viruses in influencing them in two productive freshwater reservoirs namely, Villerest and Grangent (Central France). Two dimensional nonmetric multidimensional scaling analyses indicated that bacterial communities in both reservoirs were structurally different in time and space, with Villerest harboring more diverse communities than Grangent reservoir. The bacterial communities in both reservoirs were dominated by hgcI clade (Actinobacteria) and Limnohabitans (Betaproteobacteria) which are known to have adaptive life strategies towards top-down mechanisms and resource utilization. In Villerest, thermal stratification of water column which resulted in temporary anoxia especially during summer promoted the occurrence of anoxygenic phototrophic and methanotrophic bacteria. Overall, low bacterial richness which was linked to viral lytic infection possibly suggests that a relatively small number of highly active bacterial populations sustained high bacterial activity and viral abundances. Weighted UniFrac analysis indicated that a minimum threshold viral infection and virus-to-bacteria ratio (serve as a proxy) of $10 \%$ and 10 , respectively, is required to exert its impact on phylogenetic structure of bacterial community. Therefore depending on the levels of viral infection we suggest that viruses at times can prevail over other trophic or top-down factors in shaping and structuring bacterial communities in such man-made artificial freshwater systems.

\section{Keywords}

freshwater reservoirs, bacterial community, viral lysis, 16S rRNA sequences, Illumina sequencing, microbial ecology 


\section{Introduction}

Hydroelectric reservoirs represent up to $25 \%$ of the area used for human water supply systems (irrigation, drinking water, energy generation etc.) and are identified as potentially important sources of greenhouse gas emissions (Kosten et al. 2010; Barros et al. 2011). When compared to natural lakes, these man-made lakes are considered to have different physical, chemical and biological characteristics, high disturbance frequencies with rapid, often irregular and large changes in water level and water column stability (Wetzel, 1990). Reservoirs often receive substantial amounts of anthropogenic (terrestrial) inputs from their surrounding catchment area. These interventions affect not only the water quality but also create unique habitats, enabling a broad and diverse community of bacterioplankton to thrive, which can have implications on the functioning of the ecosystems. Therefore assessing the bacterial diversity and its interactions with environmental factors is crucial to determine their ecological and biogeochemical roles in reservoir systems.

Generally high concentrations of organic matter in reservoirs tend to support higher standing stock of bacteria due to their increased growth rate and activity. Bacteria inhabiting in reservoir systems are highly dynamic and diverse (Llirós et al. 2014; Yu et al. 2014; Zhang et al. 2015), therefore in such systems bacterial community structure can be expected to vary in accordance with the prevailing environmental conditions with time and space. Compared to bottom up control (i.e. resources), knowledge on the modulation of biotic factors especially by viruses in the control of bacterial communities is scarce, owing to the lack of appropriate tools to explore biological interactions. Bottom-up factors are known to have variable impact on different bacterial communities, but still the net effect is largely dependent on mortality forces such as viral lysis or protistan grazing (Sandaa et al. 2009; Pradeep Ram et al. 2016a). Although many studies have underlined the importance of including viruses as one of the potential factors influencing bacterial community structure in freshwaters (Berdjeb et al. 2011; Llirós et al. 2014) relatively fewer investigations have been conducted in complex reservoir systems (Weinbauer et al. 2007, Pradeep Ram and Sime-Ngando 2008).

Top-down control by viruses is believed to be more host-specific and thus acts more on the community composition than size structure of the bacterial community. Studies have indicated that viruses can exert control on the most competitive and numerically dominant bacteria, thus preventing them from displacing competing taxa (Thingstad and Lignell 1997). Several lines of evidence have shown viruses to control the abundance of rare organisms through selective mortality (Bouvier and del Giorgio 2007; Pradeep Ram and Sime-Ngando 
2008), although their net influence on bacterial communities has been variable (Schwalbach et al. 2004) or limited (Jardillier et al. 2005; Berdjeb et al. 2011).

Since these man-made lake ecosystems are characterized by nutrient rich conditions, such systems could serve as potential environments for phages to attack microbes. It has been reported in reservoirs that phage lysis is responsible for up to $62 \%$ of bacterial mortality, which can contribute to recycling of carbon and nutrients through viral shunt (Pradeep Ram et al. 2016b). The impact of viruses on bacterial community dynamics is less studied compared to effects of nutrient availability. It is still unclear whether the influence of viruses on bacterial community is similar across different trophic systems. Henceforth, in the light of previously conducted studies in reservoir systems, we hypothesize that phage-host dynamics and interactions should largely influence patterns of bacterial community composition and diversity.

In the present study, two man-made lakes, namely Grangent and Villerest reservoirs which are situated across a major river (Loire, Central France) were used as model systems to evaluate viral impact on bacterial community structure in time and space. The main objectives of our study are 1) to characterize differences in bacterial community composition and dynamics (richness and composition) at a finer taxonomic scale using Illumina MiSeq sequencing of 16S rRNA amplicons over space and time and 2) to evaluate the potential impact of viral lysis on these bacterial communities. Results from the present study would add to the growing knowledge of linking bacterial community structure to the functioning of these man-made artificial ecosystems.

\section{Materials and methods}

\section{Site description and sampling}

The Grangent and Villerest reservoirs were created by dams built in 1957 and 1984 respectively across the Loire River for the purpose of generating electricity by hydroelectric plants. Both reservoirs are located in the same geographical region (Central France) with Villerest reservoir situated at a distance of $70 \mathrm{~km}$ downstream of Grangent reservoir (see Sabart et al. 2009 for map and study locations). Compilation of detailed hydrological and morphometric characteristics of the study reservoirs are presented in Table $\mathbf{1}$. These thermally stratified reservoirs experience fluctuation in water levels (up to 15 meters) due to release of water for the purpose of summertime irrigation and also to prevent deoxygenation in the deeper waters. Due to the large catchment area, both reservoirs receive high inputs of organic 
matter from the terrestrial sources which annually promote toxic bloom forming freshwater bacteria Microcystis aeuroginosa, especially during summer.

The sampling was carried out in Grangent (20 April, 13 July and 5 October) and Villerest (7 May, 30 July and 26 October) in 2015, covering three distinct seasons namely, spring, summer and autumn respectively. Triplicate water samples were collected from Villerest $\left(45^{\circ} 55^{\prime} \mathrm{N}, 4^{\circ} 02^{\prime} \mathrm{E}\right)$ and Grangent $\left(45^{\circ} 27,4^{\circ} 15^{\prime} \mathrm{E}\right)$ reservoirs using Van Dorn bottle (10 L capacity) at three different depths namely, epilimnion ( $0.5 \mathrm{~m}$ below the surface), metalimnion ( $7 \mathrm{~m}$ below the surface), and hypolimnion ( $1 \mathrm{~m}$ above the sediments). The collected water samples were immediately pre-screened through a $150 \mu \mathrm{m}$ pore size nylon filter to exclude predatory metazoan zooplankton and then transferred to sterile containers. The samples were transported to laboratory in refrigerated boxes and processed immediately upon arrival.

\section{Physico-chemical analyses}

Secchi measurements (Zs) were used to estimate the euphotic depth (Zeu) according to the relationship: Zeu $=2.42 \mathrm{Zs}$ (Wetzel and Likens 1995). Water temperature was measured directly with a field thermometer and dissolved oxygen concentration was determined by the Winkler method (Carpenter, 1965). The $\mathrm{pH}$ was determined with a standard $\mathrm{pH}$ probe $(\mathrm{pH}$ 1000L, VWR, UK). Total organic carbon were determined by high temperature catalytic oxidation method $\left(680^{\circ} \mathrm{C}\right)$ using a TOC analyzer (Shimadzu TOC-V CPN, Japan) (Lønborg and Søndergaard 2009) and total nitrogen using the same analyzer with an attached measuring unit (Mahaffey et al. 2008) with values reported after correction with instrument blank.

\section{DNA Extraction}

Bacteria from the lake water samples $(200 \mathrm{ml})$ were collected onto $0.2 \mu \mathrm{m}$ white polycarbonate membrane filters (Sartorius, Germany) in triplicates by applying gentle vacuum. Total community DNA was then extracted from filters using Fast DNA spin kit for soil (MP Biomedicals, Germany) by using two consecutive bead-beating steps, first, for $40 \mathrm{~s}$, followed by a second bead beating for $60 \mathrm{~s}$ to disrupt additional, previously un-lysed cells. Remaining steps were followed as per manufacturer's protocol. Yield and quality of the extracted DNA samples were checked on $0.8 \%$ agarose gel, and extracted genomic DNA was quantified, checked for purity at A260/280 nm by NanoDrop spectrophotometer (Thermo Scientific, USA.). The DNA was stored at $-20{ }^{\circ} \mathrm{C}$ until further processing. 


\section{PCR Amplification of 16S rRNA gene and Sequencing}

PCR amplification was carried out to amplify V3-V4 conserved regions of bacterial $16 \mathrm{~S}$ rRNA gene sequences in triplicate using the 16S rRNA gene specific primers (forward primer 5'-CTTTCCCTACACGACGCTCTTCCGATCTACGGRAGGCAGCAG-3' and reverse 5'GGAGTTCAGACGTGTGCTCTTCCGATCTTACCAGGGTATCTAATCCT-3') (Liu et al. 2007). These primers include the Illumina adapter overhang nucleotide sequences (underlined segment) as well as V3-V4-specific sequences producing an amplicon of $460 \mathrm{bp}$ in length. The libraries for 16S rRNA were prepared according to procedure as detailed in Keshri et al. (2017). Negative PCR controls were also run using Milli-Q water instead of template DNA to confirm that there was no contamination of the reagents or extraction protocol. Triplicate amplicons from respective samples were pooled together in order to decrease the PCR bias led by stochastic fluctuations in amplification efficiencies (Polz and Cavanaugh 1998) and sequenced (paired-end at a length of 300 nucleotides in each direction) on the Illumina MiSeq platform at the INRA, Toulouse, France. Pooling of PCR amplicons has been done in samples obtained from aquatic systems (Pascault et al. 2014, Li et al. 2017) without significantly influencing Illumina based sequencing data (Kennedy et al. 2014). Sequence data which were received as .fastq files was submitted to the National Center for Biotechnology Sequence Read Archive under Bio Project accession number PRJNA395988.

\section{Sequence data analysis}

Sequence processing was performed using mothur software, version 1.39.1 (Schloss et al. 2009). The paired-end MiSeq Illumina reads from the 18 samples were aligned and converted to contigs yielding 693,384 reads. Sequence analysis of each combined single fasta file was processed using the mothur MiSeq SOP accessed on the 10 December 2016 (Kozich et al. 2013). The high quality of sequences were filtered using following parameters; base quality score $\geq 20$, deltaq $=6$, match $=1$, mismatch $=-1$, gapopen $=-2$ and gapextend $=-1$. Sequences having ambiguous characters and homopolymers longer than 8 bp were removed. Highquality sequences were aligned against the mothur version of SILVA bacterial reference sequences (Pruesse et al. 2007), pre clustered, chimeras and singletons removed and OTUs were defined at $97 \%$ identity. After normalizing the number of sequences in each sample based on rarefied or subsampled data i.e. the minimum number of remaining sequences $(6,569)$ in any of the samples); rarefaction was performed on each sample to assess sampling adequacy, using a 100 sequence increment. Alpha diversity was assessed by calculating the richness Chao1 estimator, Shannon diversity, and Evenness indices. The Shannon index is the 
parametric diversity measure commonly used to characterize species diversity in a community which combines estimates of richness (total number of OTUs) and evenness (relative abundance). Beta diversity (variation in community structure between samples) is determined using the same subsampling approach with an index that accounts for proportional abundances of both shared and non-shared OTUs (Yue and Clayton 2005). Non-metric multidimensional scaling (NMDS) based on Bray-curtis distance matrix was used to visualize the similarity between samples. Similarity among bacterial community structure was assessed using Sorensen's coefficient for occurrence data (Legendre and Legendre 1998).

\section{Bacterial and viral abundances}

Samples ( $1 \mathrm{ml}$ each) for enumeration of bacterial and viral abundances were fixed with paraformaldehyde $\left(0.5 \%\right.$ final concentration) and kept in dark at $4^{\circ} \mathrm{C}$ for 30 minutes. Following fixation, the samples were immediately passed through FACS Calibur flow cytometer (Becton Dickinson, Franklin Lake, NJ, USA) equipped with an air-cooled laser providing $15 \mathrm{~mW}$ at $488 \mathrm{~nm}$ with the standard filter set-up (Brussaard et al. 2010). Briefly the extracted samples were diluted in $0.02 \mu \mathrm{m}$ filtered TE buffer $(10 \mathrm{mM}$ Tris- $\mathrm{HCl}$ and $1 \mathrm{mM}$ EDTA, pH 8), and stained with SYBR Green I (10,000 fold dilution of commercial stock, Molecular Probes, Oregon, USA). Since dilution of water samples with TE buffer depends on the in situ viral and bacterial abundances, and sensitivity of the flow cytometer, validity check and standardization was carried out before proceeding with counts. This methodology has been previously validated and adopted for reporting bacterial and viral counts in these reservoir systems (Pradeep Ram et al., 2016b). The mixture was incubated for $5 \mathrm{~min}$ at ambient temperature, heated for $10 \mathrm{~min}$ at $80^{\circ} \mathrm{C}$ in the dark, and cooled for $5 \mathrm{~min}$ at room temperature prior to analysis. Bacteria and viruses differing in fluorescence intensity were detected by their signature in a side scatter versus green fluorescence (530 nm wave- length, fluorescence channel 1 of the instrument) plot. Flow cytometry list modes were analyzed using CellQuest Pro software (BD Biosciences, San Jose, CA, USA; version 4.0). A blank was routinely examined to control for contamination of the equipment and reagents.

\section{Viral lytic infection}

Viral lytic infection was inferred from the frequency of visibly infected cells (FVIC) according to Pradeep Ram and Sime-Ngando (2008). Bacterial cells contained in $8 \mathrm{ml}$ of glutaraldehyde fixed water samples (final concentration 1\%) were collected on copper electron microscope grids (400-mesh, carbon-coated Formvar film) by ultracentrifugation 
(Beckman coulter SW 40 Ti Swing-Out-Rotor at $70000 \mathrm{x}$ g for 20 minutes at $4^{\circ} \mathrm{C}$ ). Each grid was stained at room temperature $\left(\mathrm{ca} .20^{\circ} \mathrm{C}\right)$ for $30 \mathrm{~s}$ with Uranyl acetate $(2 \% \mathrm{w} / \mathrm{w}, \mathrm{pH}=4)$, rinsed twice with $0.02 \mu \mathrm{m}$-filtered distilled water, and dried on a filter paper. Grids were examined using a JEOL $1200 \mathrm{Ex}$ transmission electron microscope (TEM) operated at $80 \mathrm{kV}$ at a magnification of 20,000 to $60,000 x$ to distinguish between bacterial cells with and without intracellular viruses. A bacterium was considered infected when at least five viruses, identified by their shape and size, were clearly visible inside the host cell. At least 400-600 bacterial cells were inspected per grid to determine FVIC (Supplementary material, Figure S1). Because mature phages are visible only late in the infection cycle, FVIC counts were converted to the frequency of infected cells (FIC) using the equation FIC $=9.524$ FVIC 3.256 (Weinbauer et al. 2002).

\section{Statistical analysis}

Differences in physicochemical and biological variables between the reservoirs were tested by one-way analysis of variance (ANOVA). We used two-way ANOVA to test the potential effects of seasons and depths on the variability in the targeted biological variables. Interactions terms were always included in the analyses. Since the data were log-transformed to satisfy the requirements of normality and homogeneity of variance necessary for parametric statistics, potential relationships between the studied environmental and microbial variables were tested by Pearson correlations analysis using Statistica 13 software package (Statsoft, Dell Software, Tulsa, OK, USA). Bacterial community composition in both the reservoirs in different seasons altogether were compared using pairwise adonis function (Martinez 2017) under devtools package in RStudio, with Bray similarity method and Bonferroni corrected $\mathrm{p}$ value. Differences in bacterial phylogenetic composition in relation to the variation in viral parameters (infection rate and viral to bacterial abundance) were assessed using weighted UniFrac distance metric (Lozupone et al. 2006) using all data combined.

\section{Results}

\section{Limnological characteristics of the reservoirs}

The physico-chemical and microbial characteristics of Grangent and Villerest during the studied months at different depths are shown in Table 2. During the sampled seasons, the euphotic depth (Zeu) was never found to exceed $7 \mathrm{~m}$ and $6 \mathrm{~m}$ for Grangent and Villerest, respectively. Water temperature and dissolved oxygen concentrations were typical of the 
sampled seasons (Table 2). Clear differences in the vertical structure of the water column with consistent thermal stratification and formation of anoxia in the bottom waters during summer were evident, similar to our previous reports (Pradeep Ram et al. 2009; 2016b). Overall $\mathrm{pH}$ ranged between 7.2 and 9.3. The concentration of potentially limiting inorganic nutrients, notably dissolved reactive phosphate in both the reservoirs was well above the threshold concentration ( $\left.>15 \mu \mathrm{g} \mathrm{l}^{-1} \mathrm{PO}_{4}-\mathrm{P}\right)$ to induce any kind of limitation for bacterial growth (Pradeep Ram et al. 2009; 2016b). Total organic carbon was significantly ( $p<0.005)$ higher in Villerest (range $=6.4$ to $9.5 \mathrm{mg} \mathrm{l}^{-1}$ ) compared to Grangent (range $=5.1$ to $7.6 \mathrm{mg} \mathrm{l}^{-1}$ ) with both lakes showing highest values in summer (Table 2). Unlike organic carbon, total nitrogen did not show any significant differences between the reservoirs; however bottom waters showed significantly higher $(\mathrm{p}<0.01)$ concentrations than surface waters. Viral and bacterial abundances in Villerest were significantly higher $(\mathrm{p}<0.001)$ than Grangent, which was eventually reflected in virus to bacteria ratio (VBR) (Table 2). Like abundances, the frequency of viral infected bacterial cells also reflected higher infection in Villerest (mean = $18.8 \%$ ) compared to Grangent (mean $=12.1 \%$ ). Two-way ANOVA indicated that FIC exhibited strong variability $(\mathrm{p}<0.0001)$ with depths and seasons and significant interaction $(\mathrm{p}$ $<0.04$ ) between depths and seasons were observed (Table 3).

\section{Sequence processing and analysis}

The paired-end sequencing of 16S rRNA gene produced a total of 655,779 raw sequences which after quality filtering, singletons and chimera removal yielded 310,220 effective sequences from Grangent and Villerest reservoirs with over 6,500 sequences in each library. These effective sequences were normalized for further analysis of diversity indices. Overall the effective sequences were clustered into 1,518 OTUs at 97\% similarity. Rarefaction curves for the samples reached saturation, which indicated that sequencing depth was sufficient to cover the whole bacterial diversity (Supplementary material, Figure S2). The Good's coverage values at the 3\% dissimilarity level were $98-100 \%$ among all samples indicating that the libraries could represent most of the species in the natural habitat.

\section{Bacterioplankton Community Diversity and its Taxonomical Distribution}

Between the lakes, Villerest recorded higher number of OTUs (range $=206-400$ ) than Grangent (range = 107-293) (Table 4). For all the samples, ANOVA indicated that Villerest harbored significantly higher estimates of species richness (Chao, $\mathrm{p}<0.02$ ) and diversity (Shannon, $\mathrm{p}<0.008$ ), suggesting that the former supported more diverse bacterial population 
at the sampled months and depths. In the reservoirs, significant difference $(p<0.003)$ in the number of observed OTUs between epilimnion and hypolimnion could be a consequence of prevailing environmental conditions. The bacterial species were most evenly distributed in the epilimnion of Villerest in spring with the highest evenness index of 0.74, whereas in Grangent the highest dominance of particular species was observed in the hypolimnion during autumn with an index of 0.59. (Table 4).

The bacterial community of the reservoirs Grangent and Villerest comprised 22 different phyla along with unclassified bacterial members with varying abundance at different depths and seasons. Among these 22 phyla, 20 were recorded in both lakes and only one phylum, namely Latescibacteria and Gracilibacteria, was exclusive to Grangent and Villerest reservoirs, respectively. The bacterial phyla were largely represented by Actinobacteria, Proteobacteria and Bacteroidetes, which covered more than $98 \%$ of the total sequences in both reservoirs. Actinobacteria was the most abundant phylum covering $21.9 \%$ to $67.1 \%$ sequences across the different depths, followed by Proteobacteria which accounted for $17.6 \%$ to $55.1 \%$ of the total sequences. Actinobacteria were most abundant in all the individual samples except in hypolimnion samples of Villerest during summer and autumn where Proteobacteria were the most abundant. The sequences from the reservoirs were classified into 41 classes, 82 orders, 172 families and 297 genera. At class level, the analyzed reservoirs presented bacterial community composition which is typical of freshwater bacterial groups (Supplementary material, Figure S3). Taxonomical affiliations showed Actinobacteria (range: 18.3\%-51.3\%), Betaproteobacteria (range: 9.7\%-32.1\%), Acidimicrobiia (range: 6.1\%-17.0\%), Sphingobacteriia (range: 5.2\%-17.0\%), Alphaproteobacteria (range: 1.9-14.3\%) and Flavobacteriia (range: $0.4 \%-14.7 \%$ ) as the six most abundant bacterial classes recovered in each reservoir.

It was observed that Frankiales was the most abundant order (35.5\% of total sequences) in all the individual samples. The second most abundant order was Acidimicrobiales followed by Burkholderiales, Sphingobacteriales, Flavobacteriales, Methylophilales, Micrococcales, Cytophagales, Sphingomonadales, Methylococcales, Rhizobiales, and Nitrosomonadales (Supplementary material, Figure S4). Genus could not be assigned to $19.3 \%$ and $21 \%$ of the total sequences in Grangent and Villerest, respectively, which underlines the hitherto untapped bacterial diversity in these lakes. Out of 293 observed genera, only 125 could account for more than $0.01 \%$ of sequences and 11 could represent for more than $1 \%$ of total sequences. Both reservoirs had 154 common genera with 113 and 26 genera exclusive to Villerest and Grangent, respectively. The two most abundant genera in 
329 Grangent and Villerest belonged to Actinobacterial hgcI clades (27.6\% of sequences), and CL500-29 marine group (11.9\% of sequences). The temporal changes of abundant genera varied at specific depth in both reservoirs (Fig. 1A and B). Another notable feature in this study is the marked presence of sequences belonging to the genera Methlylotenera in the bottom waters (autumn) of Grangent and the presence of both Methylobacteria and Methlylotenera in Villerest when temporary anoxia occurred due to thermal stratification in the bottom waters during summer.

Differences in bacterial community was demonstrated by two dimensional NMDS analyses based on bray-curtis dissimilarity scores (stress $=0.16, \mathrm{r}^{2}=0.79$ ) (Fig. 2). Similarity among bacterial communities between the reservoirs with seasons and depths were assessed on the basis of Sorensens's similarity coefficient (Supplementary material, Figure S5). Core microbiome of both reservoirs was constituted by 4 OTUs (hgcI clade, Planktophila, clade CL500-29 marine group, Sediminibacterium) which were present with relative abundance more than $1 \%$ in all the samples of Grangent and Villerest. However an additional OTU was observed separately in both the reservoirs as part of the core microbiome (another OTU from hgcI clade in Grangent and OTU representing Limnohabitans in Villerest).

\section{Viral effect on bacterial diversity and composition}

Overall, viral lytic infection was negatively correlated $(\mathrm{p}<0.05)$ to bacterial diversity indexes such as bacterial species richness $\left(R^{2}=0.54\right)$, OTUs $\left(R^{2}=0.61\right)$ and species diversity $\left(R^{2}=\right.$ 0.32). Furthermore, the total richness as assessed by number of species per sample was significantly higher $(\mathrm{p}<0.001)$ in Villerest which displayed higher mortality rates than Grangent. Permutation procedure analysis using pairwise adonis function revealed distinct differences in bacterial community composition with reservoir and seasons (Table 5). Irrespective of the depths and seasons, pairwise distance matrices from the weighted UniFrac analysis supported the claim that bacterial phylogenetic composition showed significant variability $(\mathrm{p}<0.001)$ in samples which were grouped based on threshold viral infection rates $(\mathrm{FIC}=$ below $10 \%$ and above $10 \%)$ and virus-bacteria ratio $(\mathrm{VBR}=$ below10 and above 10$)$ (Table 6).

\section{Discussion}

This study is one among the few conducted in temperate freshwater reservoirs (Villerest and Grangent) with an aim of characterizing bacterial community composition and diversity on a 
fine taxonomic level and evaluating the potential role of viruses to influence them. Two dimensional NMDS analysis suggested that the bacterial communities in both reservoirs were structurally different from each other in time and space, with Villerest harboring more diverse communities than Grangent reservoir. The variable impact of viruses on bacterial communities was evident when they were potentially linked to bacterial diversity indices. Furthermore, weighted UniFrac analysis also indicated that a minimum threshold viral infection and virus-to-bacteria ratio of $10 \%$ and 10 respectively is required to exert its impact on bacterial community structure.

\section{Bacterial community composition}

In both reservoir systems, next generation Illumina MiSeq sequencing analysis revealed the existence of a typical freshwater bacterial community (Actinobacteria, Proteobacteria and Bacteroidetes), as reported from numerous freshwater systems (Llirós et al. 2014; Zhang et al. 2015; Avila et al. 2017). Members of Actinobacteria mainly belonging to genus hgcI clade represented the majority of the total sequences in Grangent (22\%) and Villerest (17.8\%) which is higher than those obtained in freshwater lakes from the same geographical region (Keshri et al. 2017). The numerical dominance of free living hgcI clade comprising of different tribes are previously known to occupy several ecological niches in freshwater systems (Ghylin et al. 2014; Llirós et al. 2014; Hayden and Beman 2016). Despite its high abundances in the studied reservoirs, this clade showed small seasonal variations when compared to other freshwater groups, similar to observations made in other freshwater systems (Allgaier and Grossart 2006, Salcher et al. 2010). Previous reports suggest that the members of $h g c I$ clade are characterized by slower growth rates which are indicative of oligotrophic lifestyles and also known to possess several genes that likely provide a competitive advantage when scavenging for energy, carbon, nitrogen and phosphorus in freshwater habitats (Ghylin et al. 2014). Moreover, the large presence of hgcl clade in our reservoirs and elsewhere could be related to the fact that they have been qualified as defense specialists due to their small cell size and cell wall structure which protects them from protistan grazing (Jezbera et al. 2006).

Among the Proteobacteria, the class Betaproteobacteria comprising mainly the genera Limnohabitans and Polynucleobacter was the most abundant followed by class Alpha-, Gamma- and Deltaproteobacteria. The adaptability of Betaproteobacteria to outgrow other bacterial groups under nutrient relaxed conditions make this bacterial class one of the most dynamic, dominant and important groups in various freshwater environments (Salcher et al. 
2013; Keshri et al. 2017). Members of Limnohabitans, belonging to the R-BT cluster of family Comamonadaceae are known to contribute over-proportionally to total bacterioplankton biomass. Their ability to efficiently utilize algal derived substrates to sustain high growth makes them one of the important players in the carbon flow to plankton grazer food chain (Šimek et al. 2010). However their opportunistic lifestyle with resource specialization makes them highly vulnerable to predation (Salcher 2014). The significant presence of free living bacteria Polynucleobacter (family Burkholderiaceae) belonging to BET II tribe in both reservoirs are suggestive of their adaptation to heterogeneous combination of allochthonous (terrestrial) and autochthonous (aquatic) organic carbon compounds that are likely to occur in these waters (Jezbera et al. 2012; Llirós et al. 2014). The variability of Flavobacterium with sampled months and depth in both the reservoirs could be related to the concentration of organic carbon and inorganic nutrients, as they have been previously reported to appear during episodes of high bacterial production, emphasizing that resource availability is an important driver for their succession in such eutrophic lakes (Kirchman 2002; Eiler and Bertilsson 2007).

Seasonality induced changes in physico-chemical gradient in the water column especially during the period of summer stratification resulted in stark distinction in the distribution and emergence of certain bacterioplankton communities between epilimnion and hypolimnion in both reservoirs. In Villerest, stratification and oxygen depletion in hypolimnion promoted the appearance of unusual species of anoxygenic phototrophs (Rhodoferax, Brevundimonas, ) and methylotrophs (Methylobacter,Methylotenera) which are important for carbon and nutrient cycling. Although, light is a primary requisite for growth and activity of aerobic anoxygenic phototrophic bacteria, their significant presence in the dark hypolimnion is less clear. However reports suggest that they can remain viable for a limited period of time and are capable of significant growth when exposed to favorable conditions (Koblížek 2015).

\section{Viral impact on bacterial community structure}

Numerous studies have highlighted the importance of the quality and quantity of organic matter to influence bacterial community composition and diversity in reservoir systems (Llirós et al. 2014; Yu et al. 2014; Iliev et al. 2017). Therefore, under nutrient enriched conditions the rapid growth of opportunistic bacterial groups could eventually be checked by viral lysis, since viral production is linked to enhanced growth conditions of the host community. Therefore viruses through their host specificity can ultimately impact community 
size and diversity (Auguet et al. 2009; Sandaa et al. 2009; Storesund et al. 2015). In this study, significant correlation of bacterial species richness with lytic viral infection corroborates our hypothesis that viruses could serve as a potential top-down factor influencing bacterial community composition. Our data suggests that the decrease in bacterial richness with viral abundance and lytic infection contradicts the specific prediction of "killing the winner hypothesis" which presumes that viral lysis should sustain high bacterial richness (Thingstad and Lignell 1997). Low bacterial richness linked to high viral abundance has been reported from marine environments when a relatively small number of highly active bacterial populations were found to sustain high bacterial activity and also high viral abundances (Winter et al. 2005). Several possible mechanisms such as resistance, decay, and masking of receptors or viral adsorption can allow some populations to become more dominant.

Moreover a longer latent period of viruses can reduce bacterial species richness by increasing the risks that viruses in the host cells will be killed by grazing.

Significant differences in bacterial community phylogenetic structure were observed in samples when the frequency of viral infected bacterial cells and virus to bacteria ratio was above a threshold of $10 \%$ and 10 respectively. Such changes in bacterial community in relation to viral abundances and their infection rates with time and space in both the reservoirs were suggestive of viral effects on host bacterial community. We propose that both viral lysis and virus to bacteria ratio could be a good proxy as a measure of top-down control of host bacterial community. Viral infection rates of more than $10 \%$ have previously been found to have antagonistic effects on the bacterial carbon metabolism through preferential lysis of active cells in reservoir (Pradeep Ram et al. 2016b) and freshwater systems (Pradeep Ram et al. 2015). Studies from a deep-silled fjord ecosystem (Norway) have also suggest bacterial diversity to be top-down controlled by viruses under conditions of higher bacterial viral lysis (virus to bacterial ratio > 10) (Storesund et al. 2015), thus reflecting our main conclusion. However more studies are required to test our claim on the variable impact of viral lysis on bacterial communities in other aquatic systems with differing trophic levels. Viral lysis can either directly influence bacterial community structure by lysing certain members of bacterial community or impact it indirectly through the utilization of viral lysate by non-infected cells. Thus, viral infection does not seem to have an equal effect on all species in a bacterial community. In the light of our above findings, there exists a possibility that both viral infection and bacterial community structure can separately respond to some individual external or environmental factor(s) rather than viruses driving bacterial communities. 
Although nutrients have largely been viewed to be a major environmental factor controlling bacterial community, our findings provides insight on the potential role of viruses in influencing bacterial community structure. Such changes in bacterial community structure driven by viral lysis can eventually alter the overall bacterial carbon metabolism which is essentially linked to the functioning of aquatic systems. Results from the present investigation not only lends growing support to increasing evidences of viral impact on bacterial community structure from aquatic environments (Bouvier and del Giorgio 2007; Chow et al. 2014; Keshri et al. 2017), but also advances our understanding in the microbial ecology of these man-made lakes.

\section{Acknowledgements}

JK was supported by a postdoctoral fellowship from the Université Clermont Auvergne (formerly Université Blaise Pascal), Clermont Ferrand (France). We thank J. Colombet and F. Perriere for their technical assistance in flow cytometry and nutrient analysis respectively. We are grateful to the members of ATHOS Environnement, Clermont Ferrand for their technical support and in the collection of water samples. Our special thanks to Dr. Emma RochelleNewall (French National Research Institute for Sustainable Development, IRD) for her constructive comments and English corrections on the manuscript. We appreciate two anonymous reviewers for their time, effort and valuable contributions to this manuscript.

\section{Declaration of Interest: None}

\section{References}

Allgaier M, Grossart HP (2006) Diversity and seasonal dynamics of Actinobacteria populations in four lakes in northeastern Germany. Appl Environ Microbiol 72:34893497

Auguet JC, Montanié H, Hartmann HJ, Lebaron P, Casamayor EO, Catala P, Delmas D (2009) Potential effect of freshwater virus on the structure and activity of bacterial communities in the Marennes-Oleron Bay (France). Microb Ecol 57:295-306

Avila MP, Staehr PA, Barbosa FAR, Chartone-Souza E, Nascimento AMA (2017) Seasonality of freshwater bacterioplankton diversity in two tropical shallow lakes from the Brazilian Atlantic forest. FEMS Microb Ecol 93:1-7 
Barros N, Cole JJ, Tranvik LJ, Prairie YT, Bastviken D, Huszar VLM, del Giorgio PA, Roland F (2011) Carbon emission from hydroelectric reservoirs liked to reservoir age and latitude. Nat Geosci 4:593-596

Berdjeb L, Pollet T, Domaizon I, Jacquet S (2011) Effect of grazers and viruses on bacterial community structure and production in two contrasting trophic lakes. BMC Microbiol $11: 88$

Bouvier T, del Giorgio PA (2007) Key role of selective viral-induced mortality in determining marine bacterial community composition. Environ Microbiol 9:287-297

Brussaard C, Payet JP, Winter C et al (2010) Quantification of aquatic viruses by flow cytometry. In: Wilhelm SW, Weinbauer MG, Suttle C (eds) Manual of aquatic viral ecology. American Society of Limnology and Oceanography, Texas, pp 102-109

Carpenter JH (1965) The accuracy of the Winkler method for dissolved oxygen. Limnology and Oceanography 10: 135-140.

Chow TCE, Kim DY, Sachdeva R, Caron DA, Fuhrman JA (2014) Top-down controls on bacterial community structure: microbial network analysis of bacteria, T4-like viruses and protists. The ISME J 8:816-829

Eiler A, Bertilsson S (2007) Flavobacteria blooms in four eutrophic lakes: Linking population dynamics to freshwater bacterioplankton to resource availability. Appl Environ Microbiol 73:3511-3518

Ghylin TW, Garcia SL, Moya F, Oyserman BO, Schwientek P, Forest KT et al (2014) Comparative single-cell genomics reveals potential ecological niches for the freshwater acI Actinobacteria lineage. The ISME J 8:2503-2516

Hayden CJ, Beman JM (2016) Microbial diversity and community structure along a lake elevation gradient in Yosemite national park, California, USA. Environ Microbiol 18: $1782-1791$

Iliev I, Yahubyan G, Marhova M, Apostolova E, Gozmanova M, Gecheva G, Kostadinova S, Ivanova A, Baev V (2017) Metagenomic profiling of the microbial freshwater communities in two Bulgarian reservoirs. J Basic Microbiol 57:669-679

Jardillier L, Boucher D, Personnic S, Jacquet S, Thénot A, Sargos D, Amblard C, Debroas D (2005) Relative importance of nutrients and mortality factors on prokaryotic community composition in two lakes of different trophic status: Microcosm experiments. FEMS Microb Ecol 53:429-443 
Jezbera J, Hornák K, Šimek K (2006) Prey selectivity of bacterivorous protists in different size fractions of reservoir water amended with nutrients. Environ Microbiol 8:13301339

Jezbera J, Jezberova J, Koll U, Hornák K, Šimek K, Hahn MW (2012) Contrasting trends in the distribution of four major planktonic betaproteobacterial groups along a $\mathrm{pH}$ gradient of epilimnia of 72 freshwater habitats. FEMS Microb Ecol 81:467-479

Kennedy K, Hall MW, Lynch MD, Moreno-Hagelsieb G, Neufeld JD (2014) Evaluating bias of Illumina-based bacterial 16S rRNA gene profiles. Appl Environ Microbiol 80: 5717-5722

Keshri J, Pradeep Ram AS, Colombet J, Perriere F, Thouvenot A, Sime-Ngando T (2017) Differential impact of lytic viruses on the taxonomical resolution of freshwater bacterioplankton community structure. Water Res 124:129-138

Kirchman DL (2002) The ecology of Cytophaga-Flavobacteria in aquatic environments. FEMS Microb Ecol 39:91-100

Koblížek M (2015) Ecology of aerobic anoxygenic phototrophs in aquatic environments. FEMS Microb Rev 39:854-870

Kosten S, Roland F, Da Motta Marques DML, Van Nes EH, Mazzeo N, Sternberg LdaSL, Scheffer M, Cole JJ (2010) Climate-dependent $\mathrm{CO}_{2}$ emissions from lakes. Global Biogeochem Cycles 24:GB2007

Kozich JJ, Westcott SL, Baxter NT, Highlander SK, Schloss PD (2013) Development of a dual-index sequencing strategy and curation pipeline for analyzing amplicon sequence data on the MiSeq Illumina sequencing platform. Appl Environ Microbiol 79:51125120

Legendre P, Legendre L (1998) Numerical Ecology. Elsevier Science BV, Amsterdam Li S, Bronner G, Lepère C, Kong F, Shi X (2017) Temporal and spatial variations in the composition of freshwater photosynthetic picoeukaryotes revealed by MiSeq sequencing from flow cytometry sorted samples. Environ Microbiol 19:2286-2300

Liu Z, Lozupone C, Hamady M, Bushman FD, Knight R (2007) Short pyrosequencing reads suffice for accurate microbial community analysis. Nucleic Acids Res 35:e120

Llirós M, Inceoğlu Ö, García-Armisen T, Anzil A, Leporcq B, Pigneur L-M et al (2014) Bacterial community composition in three freshwater reservoirs of different alkalinity and trophic status. PLoS ONE 9:e116145

Lønborg C, Søndergaard M (2009) Microbial availability and degradation of dissolved organic carbon and nitrogen in two coastal areas. Estuar Coast Shelf Sci 81:513-520 
Lozupone C, Hamady M, Knight R (2006) UniFrac - An online tool for comparing microbial community diversity in a phylogenetic context. BMC Bioinformatics 7:371

Mahaffey C, Benitez-Nelson CR, Bidigare RR, Rii Y, Karl DM (2008) Nitrogen dynamics within a wind-driven eddy. Deep Sea Res II 55:1398-1411

Martinez Arbizu P (2017) PairwiseAdonis: Pairwise multilevel comparison using adonis. R package version 0.0 .1

Pascault N, Roux S, Artigas J, Pesce S, Leloup J, Tadonleke RD, Debroas D, Bouchez A, Humbert JF (2014) A high-throughput sequencing ecotoxicology study of freshwater bacterial communities and their responses to tebuconazole. FEMS Microb Ecol 90: $563-574$

Polz MF, Cavanaugh CM (1998) Bias in template-to-product ratios in multitemplate PCR. Appl Environ Microbiol 64:3724-3730

Pradeep Ram AS, Chaibi-Slouma S, Keshri J, Colombet J, Sime-Ngando T (2016a) Functional responses of bacterioplankton diversity and metabolism to experimental bottom-up and top-down forcings. Microb Ecol 72:347-358

Pradeep Ram AS, Colombet J, Perriere F, Thouvenot A, Sime-Ngando T (2016b) Viral regulation of prokaryotic carbon metabolism in a hypereutrophic freshwater reservoir ecosystem (Villerest, France). Front Microbiol 7:81

Pradeep Ram AS, Colombet J, Perriere F, Thouvenot A, Sime-Ngando T (2015) Viral and grazer regulation of prokaryotic growth efficiency in temperate freshwater pelagic environments. FEMS Microb Ecol 91:1-12

Pradeep Ram AS, Sabart M, Latour D, Sime-Ngando T (2009) Low effect of viruses on bacteria in deep anoxic water and sediment of a productive reservoir. Aquat Microb Ecol 55:255-265

Pradeep Ram AS, Sime-Ngando T (2008) Functional responses of prokaryotes and viruses to grazer effects and nutrient additions in freshwater microcosms. The ISME J 2:498-509

Pruesse E, Quast C, Knittel K, Fuchs BM, Ludwig W, Peplies J, Glöckner FO (2007) SILVA, a comprehensive online resource for quality checked and aligned ribosomal RNA sequence data compatible with ARB. Nucleic Acids Res 35:7188-7196

Sabart M, Pobel D, Latour D, Robin J, Salençon MJ, Humbert JF (2009) Spatiotemporal changes in the genetic diversity in French bloom-forming populations of the toxic cyanobacterium, Microcystis aeruginosa. Environ Microbiol Rep 1:263-272

Salcher MM (2014) Same but different: ecological niche partitioning of planktonic freshwater prokaryotes. J Limnol 73:74-87 
Salcher MM, Pernthaler J, Posch T (2010) Spatiotemporal distribution and activity patterns of bacteria from three phylogenetic groups in an ologomesotrophic lake. Limnol Oceanogr 55:846-586

Salcher MM, Posch T, Pernthaler J (2013) In situ substrate preferences of abundant bacterioplankton populations in a prealpine freshwater lake. The ISME J 7:896-907

Sandaa R-A, Gomez-Consarnau L, Pinhassi J, Riemann L, Malits A, Weinbauer MG et al (2009) Viral control of bacterial biodiversity—evidence from a nutrient enriched marine mesocosm experiment. Environ Microbiol 11:2585-2597

Schloss PD, Westcott SL, Ryabin T, Hall JR, Hartmann M, Hollister EB et al (2009) Introducing mothur: open-source, platform-independent, community-supported software for describing and comparing microbial communities. Appl Environ Microbiol 75:7537-7541

Schwalbach M, Hewson I, Fuhrman J (2004) Viral effects on bacterial community composition in marine plankton microcosms. Aquat Microb Ecol 34:117-127

Šimek K, Kasalický V, Jezbera J, Jezberova J, Hejzlar J, Hahn MW (2010) Broad habitat range of the phylogenetically narrow R-BT065 cluster, representing a core group of the betaproteobacterial genus Limnohabitans. Appl Environ Microbiol 76:631-639

Storesund JE, Erga SR, Ray JL, Thingstad TF, Sandaa RA (2015) Top-down and bottom-up control on bacterial diversity in a western Norwegian deep-silled fjord. FEMS Microb Ecol 91:fiv076

Thingstad TF, Lignell R (1997) Theoretical models for the control of bacterial growth rate, abundance, diversity and carbon demand. Aquat Microb Ecol 13:19-27

Weinbauer MG, Hornak K, Jezbera J, Nedoma J, Dolan JR, Šimek K (2007) Synergistic and antagonistic effects of viral lysis and protistan grazing on bacterial biomass, production and diversity. Environ Microbiol 9:777-788

Weinbauer MG, Winter C, Hofle MG (2002) Reconsidering transmission electron microscopy based estimates of viral infection of bacterioplankton using conversion factors derived from natural communities. Aquat Microb Ecol 27:103-110

Winter C, Smit A, Herndl GJ, Weinbauer MG (2005) Linking bacterial abundance with viral abundance and prokaryotic activity. Limnol Oceanogr 50:968-977

Wetzel RG (1990) Reservoir ecosystems: Conclusions and speculations. In: Thornton KW, Kimmel BL, Payne FE (eds) Reservoir Limnology. John Wiley and Sons, New York, pp 227-238

Wetzel RG, Likens GE (1995) Limnological analysis, 2nd edn. Springer-Verlag, New York 
631 Yu Z, Yang J, Amalfatino S, Yu X, Liu L (2014) Effects of water stratification and mixing on microbial community structure in a subtropical deep reservoir. Sci Rep 4:5821

633 Yue JC, Clayton MK (2005) A similarity measure based on species proportions. Commun 634 Stat - Theory Methods 34:2123-2131

635 Zhang HH, Chen SN, Huang TL, Ma WX, Xu JL, Sun X (2015) Vertical distribution of 636 bacterial community diversity and water quality during the reservoir thermal 637 stratification. Int J Pub Health 12:6933-6945 


\section{$638 \quad$ Figure Legends}

639

640 Fig 1. Taxonomical distribution of major bacterial genera with seasons and depths in

641 Grangent (A) and Villerest (B) reservoirs based on the relative abundances obtained from 16S

642 rRNA gene sequencing analysis of DNA. Remaining genera are presented as others.

643

644 Fig 2. Non-metric multidimensional scaling plots of bacterioplankton communities from

645 investigated reservoirs (stress $=0.16, \mathrm{r}^{2}=0.79$ ). 


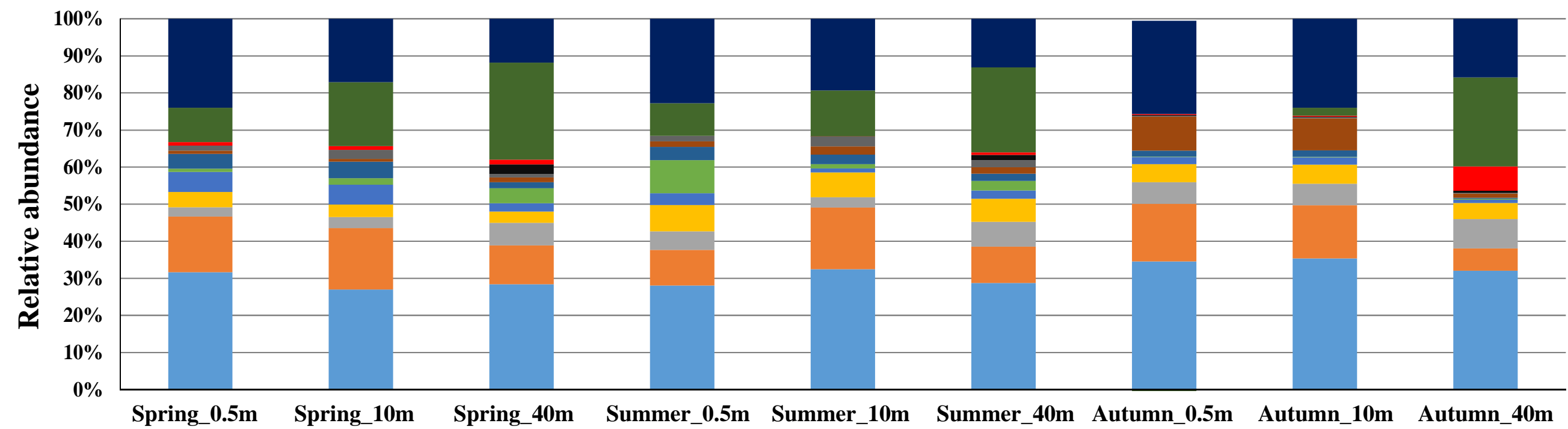

B

Villerest

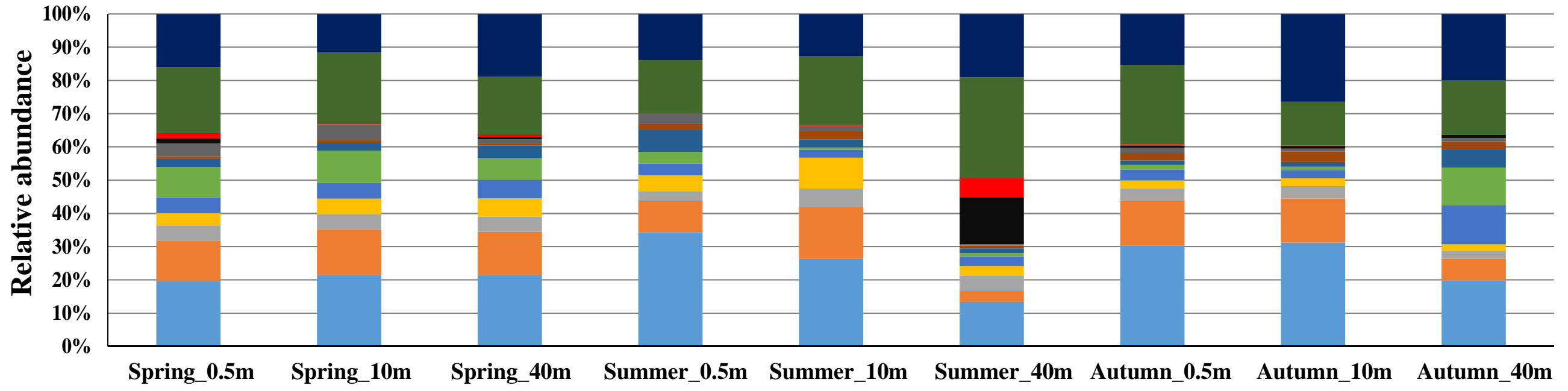

- hgcI_clade

- Flavobacterium

- Methylotenera
-CL500-29_marine_group

- Polynucleobacter

-Others

\begin{abstract}
- Sediminibacterium
- LD28_freshwater_group

- Unclassified
\end{abstract}

\section{Candidatus_Planktophila \\ - Fluviicola \\ Limnohabitans \\ - Methylobacter}

Fig. 1. Pradeep Ram et al. 


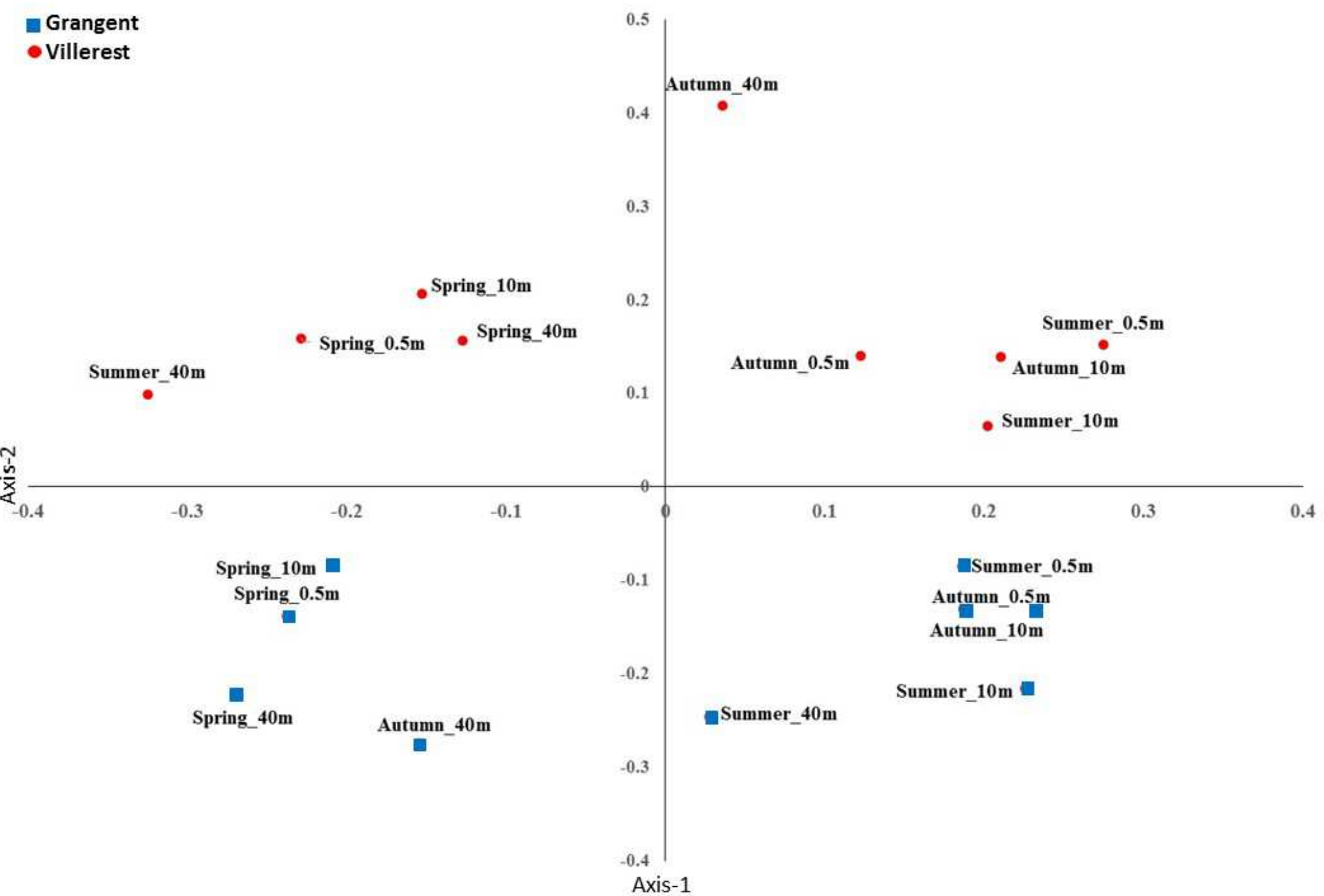

Fig. 2. Pradeep Ram et al. 
Table 1. Hydrological and morphometric characteristics of Grangent and Villerest reservoirs

\begin{tabular}{|c|c|c|}
\hline Characteristic & Grangent & Villerest \\
\hline Altitude (m) & 420 & 315 \\
\hline Trophic status & Eutrophic & Hyper-eutrophic \\
\hline Maximum depth (m) & 50 & 45 \\
\hline Maximum length $(\mathrm{km})$ & 21 & 40 \\
\hline Maximum width (m) & 400 & 900 \\
\hline Water circulation & holomictic & holomictic \\
\hline Water residence time (months) & 1 & 3 \\
\hline Surface area (ha) & 365 & 3000 \\
\hline Storage capacity $\left(10^{6} \mathrm{~m}^{3}\right)$ & 57.4 & 128 \\
\hline Water shed area $\left(\mathbf{k m}^{2}\right)$ & 3850 & 6520 \\
\hline Catchment/lake area ratio & 1055 & 217 \\
\hline Sedimentation rate $\left(\mathrm{cm} \mathrm{yr}^{-1}\right)$ & 2.0 & 3.4 \\
\hline
\end{tabular}

Source: Sabart et al. (2009) and author's compilation 
Table 2. Mean (SD) environmental characteristics of the water column of Grangent and Villerest reservoirs.

\begin{tabular}{|c|c|c|c|c|c|c|c|c|c|c|c|}
\hline Lake & Seasons & $\begin{array}{l}\text { Depth } \\
\text { (m) }\end{array}$ & $\begin{array}{l}\text { Temp } \\
\left({ }^{\circ} \mathrm{C}\right)\end{array}$ & $\begin{array}{c}\mathrm{DO} \\
\left(\mathrm{mg} \mathrm{l}^{-1}\right)\end{array}$ & $\mathrm{pH}$ & $\begin{array}{c}\text { TOC } \\
\left(\mathrm{mg} \mathrm{l}^{-1}\right)\end{array}$ & $\begin{array}{c}\mathrm{TN} \\
\left(\mathrm{mg} \mathrm{l}^{-1}\right)\end{array}$ & $\begin{array}{c}\text { Viruses } \\
\text { (x } 10^{7} \text { virus } \\
\text { like particles } \\
\mathrm{ml}^{-1} \text { ) }\end{array}$ & $\begin{array}{c}\text { Bacteria } \\
\left(\times 10^{6} \text { cells } \mathrm{ml}^{-1}\right)\end{array}$ & VBR & $\begin{array}{l}\text { FIC } \\
(\%)\end{array}$ \\
\hline \multirow{9}{*}{ 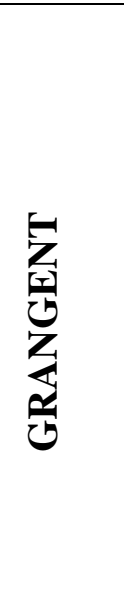 } & Spring & 0.5 & $14.3 \pm 0.2$ & $11.2 \pm 0.4$ & $7.3 \pm 0.2$ & $5.4 \pm 0.3$ & $1.2 \pm 0.2$ & $0.7 \pm 0.1$ & $2.5 \pm 0.1$ & $2.8 \pm 0.2$ & $19.6 \pm 0.9$ \\
\hline & & 5 & $12.4 \pm 0.2$ & $10.8 \pm 0.4$ & $7.6 \pm 0.3$ & $5.3 \pm 0.2$ & $1.3 \pm 0.1$ & $0.7 \pm 0.1$ & $2.7 \pm 0.2$ & $2.6 \pm 1.3$ & $9.1 \pm 0.8$ \\
\hline & & 40 & $5.8 \pm 0.1$ & $8.1 \pm 0.3$ & $7.3 \pm 0.1$ & $5.1 \pm 0.3$ & $1.6 \pm 0.2$ & $0.7 \pm 0.1$ & $2.1 \pm 0.2$ & $3.3 \pm 0.4$ & $8.2 \pm 0.7$ \\
\hline & Summer & 0.5 & $20.3 \pm 0.2$ & $7.3 \pm 0.5$ & $7.8 \pm 0.2$ & $7.7 \pm 0.3$ & $0.8 \pm 0.1$ & $5.9 \pm 0.3$ & $2.8 \pm 0.3$ & $21.1 \pm 0.9$ & $27.2 \pm 1.0$ \\
\hline & & 5 & $20.2 \pm 0.3$ & $7.0 \pm 0.4$ & $7.7 \pm 0.3$ & $7.6 \pm 0.2$ & $0.8 \pm 0.2$ & $2.0 \pm 0.2$ & $2.0 \pm 0.1$ & $10.0 \pm 0.5$ & $12.6 \pm 0.9$ \\
\hline & & 40 & $6.6 \pm 0.1$ & ND & $7.5 \pm 0.2$ & $7.2 \pm 0.3$ & $1.3 \pm 0.1$ & $1.8 \pm 0.1$ & $1.2 \pm 0.1$ & $15.0 \pm 0.9$ & $7.5 \pm 0.4$ \\
\hline & Autumn & 0.5 & $15.6 \pm 0.1$ & $6.2 \pm 0.4$ & $7.6 \pm 0.1$ & $7.0 \pm 0.2$ & $1.5 \pm 0.2$ & $0.8 \pm 0.05$ & $1.2 \pm 0.2$ & $6.7 \pm 0.4$ & $13.7 \pm 0.5$ \\
\hline & & 5 & $15.7 \pm 0.2$ & $6.0 \pm 0.3$ & $8.3 \pm 0.2$ & $6.5 \pm 0.3$ & $1.4 \pm 0.2$ & $0.8 \pm 0.03$ & $1.1 \pm 0.2$ & $7.3 \pm 0.3$ & $7.2 \pm 0.5$ \\
\hline & & 40 & $7.2 \pm 0.1$ & $0.4 \pm 0.1$ & $7.8 \pm 0.2$ & $5.2 \pm 0.4$ & $1.9 \pm 0.1$ & $1.1 \pm 0.1$ & $1.3 \pm 0.2$ & $8.4 \pm 0.5$ & $5.3 \pm 0.2$ \\
\hline \multirow{9}{*}{ 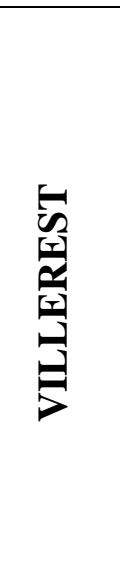 } & Spring & 0.5 & $13.4 \pm 0.2$ & $10.2 \pm 0.6$ & $7.6 \pm 0.3$ & $6.4 \pm 0.3$ & $1.6 \pm 0.2$ & $22.3 \pm 2.3$ & $29.2 \pm 1.5$ & $7.6 \pm 0.3$ & $14.3 \pm 1.1$ \\
\hline & & 5 & $12.1 \pm 0.2$ & $8.4 \pm 0.4$ & $7.6 \pm 0.1$ & $6.8 \pm 0.2$ & $1.6 \pm 0.2$ & $49.2 \pm 2.1$ & $29.1 \pm 1.2$ & $16.9 \pm 0.9$ & $26.0 \pm 1.3$ \\
\hline & & 40 & $11.7 \pm 0.1$ & $7.5 \pm 0.5$ & $7.2 \pm 0.1$ & $7.2 \pm 0.3$ & $1.9 \pm 0.3$ & $27.9 \pm 1.5$ & $26.3 \pm 2.3$ & $10.6 \pm 0.8$ & $17.0 \pm 1.1$ \\
\hline & Summer & 0.5 & $23.9 \pm 0.2$ & $13.3 \pm 0.5$ & $9.3 \pm 0.3$ & $8.8 \pm 0.5$ & $0.8 \pm 0.1$ & $17.3 \pm 1.2$ & $21.4 \pm 2.1$ & $8.1 \pm 0.3$ & $12.5 \pm 0.8$ \\
\hline & & 5 & $20.5 \pm 0.2$ & $9.8 \pm 0.4$ & $8.3 \pm 0.2$ & $8.9 \pm 0.6$ & $1.2 \pm 0.1$ & $23.3 \pm 2.3$ & $22.1 \pm 1.9$ & $10.5 \pm 0.8$ & $13.0 \pm 0.5$ \\
\hline & & 40 & $12.7 \pm 0.1$ & ND & $7.1 \pm 0.1$ & $7.9 \pm 0.2$ & $1.9 \pm 0.2$ & $16.0 \pm 1.5$ & $16.2 \pm 1.2$ & $10.0 \pm 0.9$ & $12.5 \pm 0.7$ \\
\hline & Autumn & 0.5 & $17.2 \pm 0.2$ & $7.0 \pm 0.3$ & $7.4 \pm 0.2$ & $7.8 \pm 0.3$ & $0.5 \pm 0.01$ & $12.2 \pm 1.9$ & $16.4 \pm 1.2$ & $7.4 \pm 0.5$ & $7.5 \pm 0.5$ \\
\hline & & 5 & $17.1 \pm 0.1$ & $6.0 \pm 0.2$ & $7.5 \pm 0.2$ & $8.1 \pm 0.2$ & $0.8 \pm 0.05$ & $10.9 \pm 1.4$ & $15.2 \pm 1.5$ & $7.2 \pm 0.4$ & $9.0 \pm 0.4$ \\
\hline & & 40 & $15.6 \pm 0.2$ & $5.9 \pm 0.3$ & $7.5 \pm 0.1$ & $9.5 \pm 0.4$ & $2.7 \pm 0.2$ & $16.4 \pm 1.2$ & $20.3 \pm 1.4$ & $8.1 \pm 0.3$ & $11.5 \pm 0.6$ \\
\hline
\end{tabular}

Temp: water temperature, DO: dissolved oxygen, TOC: total organic carbon, TN: total nitrogen, VBR: virus to bacteria ratio, FIC: frequency of infected cells ND : not detected 
Table 3. Two-way ANOVA values for the effects of seasons and depths on viruses, bacteria, virus to bacteria ratio and frequency of infected cells in Grangent and Villerest Reservoir. Degrees of freedom are 2, 2, 4, and 18 for A, B, AB and error, respectively. $F$, F ratio and $P$, probability.

\section{GRANGENT}

\begin{tabular}{ccccccccc}
\hline Source & \multicolumn{2}{c}{ Viruses } & \multicolumn{2}{c}{ Bacteria } & \multicolumn{2}{c}{ Virus to Bacteria ratio } & \multicolumn{2}{c}{ Frequency of infected cells } \\
& $F$ & $P$ & $F$ & $P$ & $F$ & $P$ & $F$ & $P$ \\
\hline Seasons (A) & 17.88 & 0.0001 & 25.27 & 0.0001 & 57.64 & 0.0001 & 20.57 & 0.0001 \\
Depths (B) & 4.86 & 0.018 & 7.00 & 0.004 & 4.99 & 0.016 & 76.74 & 0.0001 \\
Interactions (A x B) & 450.03 & 0.0001 & 80.00 & 0.0001 & 39.85 & 0.0001 & 40.67 & 0.0001 \\
\hline
\end{tabular}

\section{VILLEREST}

\begin{tabular}{cccccccc}
\hline Source & \multicolumn{2}{c}{ Viruses } & \multicolumn{2}{c}{ Bacteria } & \multicolumn{2}{c}{ Virus to Bacteria ratio } & \multicolumn{2}{c}{ Frequency of infected cells } \\
& $F$ & $P$ & $F$ & $P$ & $F$ & 0.0001 & 25.70 \\
\hline Seasons (A) & 25.67 & 0.0001 & 51.17 & 0.0001 & 11.25 & 0.0001 & 0.001 \\
Depths (B) & 76.4 & 0.003 & 0.84 & 0.444 & 10.00 & 0.005 \\
Interactions (A x B) & 994.49 & 0.0001 & 123.27 & 0.0001 & 140.52 & 0.0001 \\
\hline
\end{tabular}


Table 4. Bacterial diversity indices along the vertical water column of Grangent and Villerest.

\begin{tabular}{|c|c|c|c|c|c|c|c|}
\hline Lake & Seasons & Depth (m) & Goods Coverage & OTUs & Chao & Shannon index & Shannon evenness \\
\hline \multirow{9}{*}{ GRANGENT } & Spring & 0.5 & 0.99 & 193 & 256 & 3.38 & 0.64 \\
\hline & & 5 & 0.99 & 182 & 257 & 3.60 & 0.69 \\
\hline & & 40 & 0.99 & 198 & 231 & 3.64 & 0.69 \\
\hline & Summer & 0.5 & 1.00 & 107 & 107 & 3.38 & 0.72 \\
\hline & & 5 & 0.99 & 211 & 238 & 3.71 & 0.69 \\
\hline & & 40 & 0.99 & 273 & 309 & 3.98 & 0.71 \\
\hline & Autumn & 0.5 & 0.99 & 246 & 294 & 3.74 & 0.68 \\
\hline & & 5 & 0.98 & 293 & 428 & 3.82 & 0.67 \\
\hline & & 40 & 0.98 & 280 & 391 & 3.34 & 0.59 \\
\hline \multirow{9}{*}{ VILLEREST } & Spring & 0.5 & 0.99 & 308 & 372 & 4.22 & 0.74 \\
\hline & & 5 & 0.99 & 265 & 332 & 4.03 & 0.72 \\
\hline & & 40 & 0.99 & 314 & 374 & 3.98 & 0.69 \\
\hline & Summer & 0.5 & 0.99 & 206 & 250 & 3.60 & 0.68 \\
\hline & & 5 & 0.99 & 266 & 312 & 3.84 & 0.69 \\
\hline & & 40 & 0.98 & 388 & 457 & 4.09 & 0.69 \\
\hline & Autumn & 0.5 & 0.99 & 393 & 458 & 4.28 & 0.72 \\
\hline & & 5 & 0.99 & 400 & 447 & 4.31 & 0.72 \\
\hline & & 40 & 0.98 & 400 & 498 & 4.37 & 0.73 \\
\hline
\end{tabular}


Table 5. Pairwise Adonis on Bray-Curtis dissimilarities showing the differences in bacterial community structure between the reservoirs in different seasons

\begin{tabular}{lcc}
\hline Test for differences between lakes and sampling dates & $\mathrm{R}^{2}$ & $\mathrm{P}$ \\
\hline Grangent versus Villerest (Global) & 0.11 & 0.03 \\
Spring versus Summer & 0.24 & 0.003 \\
Summer versus Autumn & 0.16 & 0.147 \\
Spring versus Autumn & 0.25 & 0.015
\end{tabular}


Table 6. Weighted UniFrac analysis of lakes exhibiting variable viral infection and virus to bacteria ratio.

\begin{tabular}{lccc}
\hline UniFrac & WScore & $\mathrm{p}$ \\
\hline Viral infection rate at above and below the threshold value of 10\% & 0.53 & 0.001 \\
Virus to bacteria ratio at above and below the threshold value of 10 & 0.46 & 0.001 \\
\hline
\end{tabular}

